\title{
CAN ANTS CONTRIBUTE TO THE CONSERVATIVE BIOLOGICAL CONTROL OF THE SOUTH AMERICAN FRUIT FLY?
}

\author{
FORMIGAS PODEM CONTRIBUIR PARA O CONTROLE BIOLÓGICO \\ CONSERVATIVO DA MOSCA-DAS-FRUTAS SUL-AMERICANA?
}

\author{
Lenon Morales ABEIJON ${ }^{1}$; Alexandra Peter KRUGER ${ }^{1}$; Junir Antonio LUTINSKI ${ }^{1}$; \\ Flávio Roberto Mello GARCIA ${ }^{1}$ \\ 1. Programa de Pós-Graduação em Entomologia, Instituto de Biologia, Universidade Federal de Pelotas, Pelotas, RS, Brasil. \\ flavio.garcia@ufpel.edu.br; 2. Programa de Pós-Graduação em Ciências da Saúde, Universidade Comunitária da Região de Chapecó, \\ Chapecó, SC, Brasil
}

\begin{abstract}
Ants (Hymenoptera, Formicidae) are an efficient group of insects as predators of various arthropods. Based on records of the predatory ant activity, a survey was carried out on the efficiency in predation of Anastrepha fraterculus (Diptera: Tephritidae) larvae, considering the percentage of removal of larvae using the variables of soil density and moisture content and their effect on the larvae burying. For this, $A$. fraterculus larvae were released to the soil and observed for 10 min while burying or removed by the ants in a peach (Prunus persica, Rosaceae) orchard. Eight ant species were recorded removing $32.70 \%$ of the larvae. Solenopsis saevissima was the most efficient species, with $42.86 \%$ of larvae removal. There were no significant correlations between the predation by ants with soil density and soil moisture content. Despite this, the study pointed out that ants belong to genera Pachycondyla, Pheidole, Pogonomyrmex and Solenopsis can be predators on A. fraterculus larvae, with emphasis on the S. saevissima. These ants can contribute as important agents of conservative biological control of the population of A. fraterculus in peach orchard and their conservation becomes interesting to use of combined control methods aiming to reduce insecticides and aggressive soil management methods.
\end{abstract}

KEYWORDS: Insect ecological management. Anastrepha fraterculus. Natural enemy. Prunus persica. Solenopsis. Tephritidae

\section{INTRODUCTION}

Female fruit flies lay eggs on the fruits, and the larvae feed on the pulp. The quality of the fruits for fresh consumption and industrialization is compromised due to the damage caused by larvae (ALBERTI et al., 2009, NICÁCIO et al., 2018). The adequacy to the demands of the consumer market and the search for food safety, require rapid changes in the control techniques (DUARTE et al. 2016, MARTINS et al., 2018). These changes are important for the supply of high quality fruits, free from pests, diseases and physiological disturbances, able to conquer new markets (VELOSO et al., 2012).

Among tephritids, the genus Anastrepha Schiner, 1868 is the most diverse and economically relevant in the Americas (MARSARO JUNIOR et al., 2013). This genus is endemic to the New World, restricted to tropical and subtropical environments and comprises approximately 235 species, divided into 18 groups.

In this perspective, biological control becomes a fundamental tool in the management of agricultural pests, because it has relatively lower cost, is more selective and less risk to human health and the environment.

Parasitoids, such as Diachasmimorpha longicaudata Ashmead, 1905 (Hymenoptera: Braconidae) are effective biocontrol agents of Anastrepha species and Ceratitis capitata (Wiedemann, 1824) (Diptera: Tephritidae) (GARCIA; RICALDE, 2013). However, the use of predators in management programs of fruit flies is little known.

Ants are an efficient group of predatory insects that control insect populations (ESKAFI; KOLBE, 1990; RADEGHIERI, 2004) and can be considered as pest control agents in agroecosystems. The predation of fruit flies by ants occurs when the larva leaves the fruit to bury into the soil and pupate (FERNANDES et al., 2012). The larvae accommodation is strongly influenced by soil physical properties, causing the larva to take more time to bury in dry soils, increasing the time they are exposed to predation by a variety of predators (ALUJA et al., 2005).

The interactions among physical soil properties, the survival and the developmental stages of insects living in the soil were studied for 
some groups, such as Noctuidae lepidopterans (ROACH; CAMPBELL, 1983) and Chrysomelidae coleopterans (REGNIERE et al., 1981; MARRONE; STEINNER, 1983).

The objective of this study was to evaluate the predation rate of Anastrepha fraterculus (Wiedemann, 1830) larvae by ants considering the level of soil compaction and soil moisture content in peach (Prunus persica, Rosaceae) orchard.

\section{MATERIAL AND METHODS}

\section{Study area}

The study was carried out in a peach orchard (Height of plant: 2.0 to 2.5 meters, age: 4 years old) under a conventional system, in a rural area of the municipality of Morro Redondo, State of Rio Grande do Sul, Brazil (31 ${ }^{\circ} 33^{\prime}$ S; 52 $32^{\circ} 38^{\prime} \mathrm{W}, 278$ $\mathrm{m}$ of altitude). It is located in the physiographic micro-region known as Serras de Sudeste, which presents a natural vegetation cover classified as small-scale forest and fields, approaching the savannah (PORTO, 2002). The climate is humid subtropical climate (ALVARES et al., 2013). The orchard has an area of one hectare and is grown 500 plants of the cultivar Vanguarda (medium cycle). The orchard presents, as cultural treatments to reduce the effect of spontaneous plants, the mechanical (with the aid of a tractor) and chemical weeding (application of glyphosate at $1 \mathrm{~mL}$ commercial product per $\mathrm{L}$ water). The application of fungicides such as carbendazim on flowers and tebuconazole on the green fruits and soil fertilization with application of the dosage of 12-0$0-0$ of calcium nitrate.

\section{Predation experiment}

The trial, to evaluate the predation of ants on A. fraterculus, was performed according to a described methodology (FERNANDES et al., 2012). The trial had the randomization of 50 peach plants, delimiting an area of $1 \mathrm{~m}^{2}$ (quadrant) under the canopies of the selected plants, and removing all plant biomass the day before the experiment with the purpose of facilitating observation and the capture by the ants. In these quadrants, three $3^{\text {rd }}$ instar A. fraterculus were offered. The fruit flies were obtained from a laboratory colony reared in artificial diet (NUNES et al., 2013), kept in the Laboratório de Biologia de Insetos, of the Departamento de Fitossanidade of the Faculdade de Agronomia Eliseu Maciel/“Universidade Federal de Pelotas (UFPel)". The larvae were individually released at a height of approximately $30 \mathrm{~cm}$ from the ground, simulating the larvae leaving the fruit.
All the trials were carried out during the fruiting and harvesting period of the peach cultivar and during the same period of the day (between 7:00 and 11:00 $\mathrm{AM}$ ), as a function of the natural luminosity for field observation, for a total of $8.3 \mathrm{~h}$ of observations.

In order to avoid the larvae death in the transportation from the laboratory until the field release, a recommendation was followed (THOMAS, 1995), keeping them in a collecting container with a small amount of distilled water to maintain the larval moisture and to inhibit pupation.

The evaluation was characterized by recording for $10 \mathrm{~min}$ with the aid of a Sony Handycam digital camcorder (model HDR-PJ200), attached to a tripod, after the moment of release of the larva when it reached the ground, extending to the time it was buried in the soil (TE: burial time). If there was an ant predation and larvae removal, this information was evaluated by the time spent by the ants to remove it (TR: time to remove the larva). Removal was considered as every attack made by the ants to the place where the larvae started burial. Altogether, there was a total of $500 \mathrm{~min}$ of recording. All of the ants registered to remove $A$. fraterculus larvae were actively collected, stored in cryogenic tubes of $12 \times 45 \mathrm{~mm}$, identified with labels and transported to the Laboratorio de Ecologia de Insetos of the Departamento de Ecologia, Zoologia e Genética of Instituto de Biologia of the UFPel. Ants were morphotyped and identified at the genus or species level according to keys proposed (FERNÁNDEZ, 2003). The third author of this article identified ants. Voucher specimens were deposited at the Museu Entomológico Ceslau Biezanko of the UFPel.

After each observation, soil samples were taken at the layer of 0 to $5 \mathrm{~cm}$, using $5 \mathrm{~cm}$ soil sample rings, stored and sealed with tape in a tin container and transported to the Laboratorio de Ecologia de Insetos, for physical soil analysis.

The soil samples were analyzed for soil density (Sd) by the soil sample ring method and current soil moisture content (Gravimetric Humidity, Gh). The determination of the current moisture content of the soil was carried out with the same volumetric rings, recording the weight of the sample with the humidity of the field, placing it in an oven at $110{ }^{\circ} \mathrm{C}$ for $24 \mathrm{~h}$, and calculating the quotient of the difference between wet mass and dry mass by sample volume. Soil density was determined by the ratio of the dry mass and volume of the cylindrical ring. For this, the ring volume was recorded and the dry mass of the sample was determined. 


\section{Data analysis}

Multiple regression analysis was used to evaluate the mean burial time related to soil moisture, soil compaction and interaction between these two variables. In addition, principal component analysis (PCA) was applied with the aid of the PAST statistical software (HAMMER et al., 2001).

\section{RESULTS}

Of the total of 150 larvae of $A$. fraterculus released to the soil, $41(27.3 \%)$ were removed by the ants and $42(28.0 \%)$ were buried. Of these, 59
ABEIJON, L. M. et al.

(39.3\%) were not buried in the soil and were not removed by the ants. In addition, eight larvae $(5.3 \%)$ were buried and soon afterwards were removed by the ants.

In all, eight species of ants of four genera belonging to two subfamilies were recorded removing A. fraterculus larvae. The records of the subfamily Myrmicinae were Pheidole Westwood, 1839, Pogonomyrmex Mayr, 1868 and Solenopsis Westwood, 1840. The subfamily Ponerinae was represented by only Pachycondyla Smith, 1858. Solenopsis saevissima (Smith, 1855) (Myrmicinae) performed the largest larvae removal, with $42.9 \%$ (Table 1).

Table 1. Removal percentage of 49 Anastrepha fraterculus larvae by ant species in a peach orchard between 7:00 and 11:00 AM, municipality of Morro Redondo, State of Rio Grande do Sul, Brazil between October 2014 and February 2015.

\begin{tabular}{ll}
\hline Species or morphospecies & Removal rate (\%) \\
\hline Solenopsis saevissima & 42.9 \\
Pheidole sp. 1 & 18.4 \\
Pheidole sp. 5 & 12.2 \\
Pheidole sp. 2 & 10.2 \\
Pachycondyla striata & 6.1 \\
Pheidole sp. 3 & 4.1 \\
Pogonomyrmex naegelli & 4.1 \\
Pheidole sp. 4 & 2.0 \\
\hline
\end{tabular}

The ants of the genus Pheidole were five morphospecies, in which Pheidole sp. 1 performed the greatest removal of larvae $(18.4 \%)$, followed by Pheidole sp. 5 (12.2\%), Pheidole sp. 2 (10.2\%), Pheidole sp. 3 (4.1\%) and Pheidole sp. 4 (2.0\%) and Pogonomyrmex naegelli Forel, 1878 the only one of the genus, recorded $4.1 \%$ of removal. Pachycondyla striata F. Smith, 1858, the only ant of the subfamily Ponerinae, removed $6.12 \%$ of the larvae released.
From the total of 500 minutes recorded, the ants spent on average about $4.44 \mathrm{~min}$ in the removal of $A$. fraterculus larvae. The individuals belonging to Pheidole sp. 1 spent 3.47 minutes, the shortest average time of removal (Table 2). In addition to removal by only one ant, in some species, recruitment behavior was observed in the removal by $S$. saevissima.

Table 2. Removal average (minutes) of Anastrepha fraterculus larvae by ant species in a peach orchard, municipality of Morro Redondo, State of Rio Grande do Sul, Brazil between October 2014 and February 2015.

\begin{tabular}{ll}
\hline Ant & Removal time (minutes) \\
\hline Pachycondyla striata & 6.4 \\
Pogonomyrmex naegelli & 5.8 \\
Pheidole sp. 2 & 5.0 \\
Pheidole sp. 4 & 5.9 \\
Pheidole sp. 5 & 5.4 \\
Solenopsis saevissima & 4.0 \\
Pheidole sp. 3 & 3.8 \\
Pheidole sp. 1 & 3.5 \\
\hline
\end{tabular}

There were significant differences related to the burial time of $A$. fraterculus larvae with $\mathrm{Sd}(\mathrm{p}=$ 0.0342) (Figure 1).
In addition, statistical significance was also reached between burial time and soil moisture content $(\mathrm{p}=0.0001)$ (Figure 2). 
Despite the efficiency of the ants in the time for removal of larvae, the principal component 1 , which correlated TR with Ds, was able to explain $58.07 \%$ of variability and showed low correlation with density (Figure 3). However, the principal component 2 explained about $41.36 \%$ of the variation and correlated TR with $\mathrm{Ug}$.

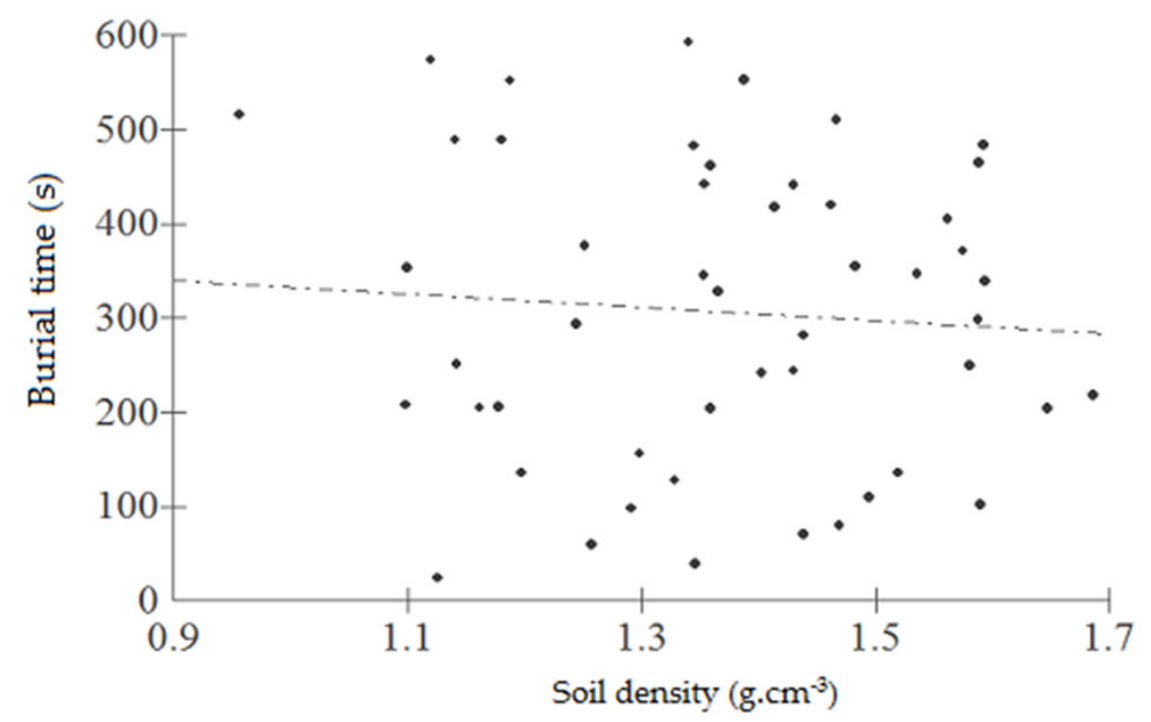

Figure 1. Linear regression of burial time (Bt, seconds) in an experiment to simulate Anastrepha fraterculus larvae leaving the fruit at a height of $30 \mathrm{~cm}$ from the ground and soil density $(\mathrm{Sd})\left(\mathrm{g} . \mathrm{cm}^{-3}\right)$, in a peach orchard, municipality of Morro Redondo, State of Rio Grande do Sul, Brazil between October 2014 and February 2015.

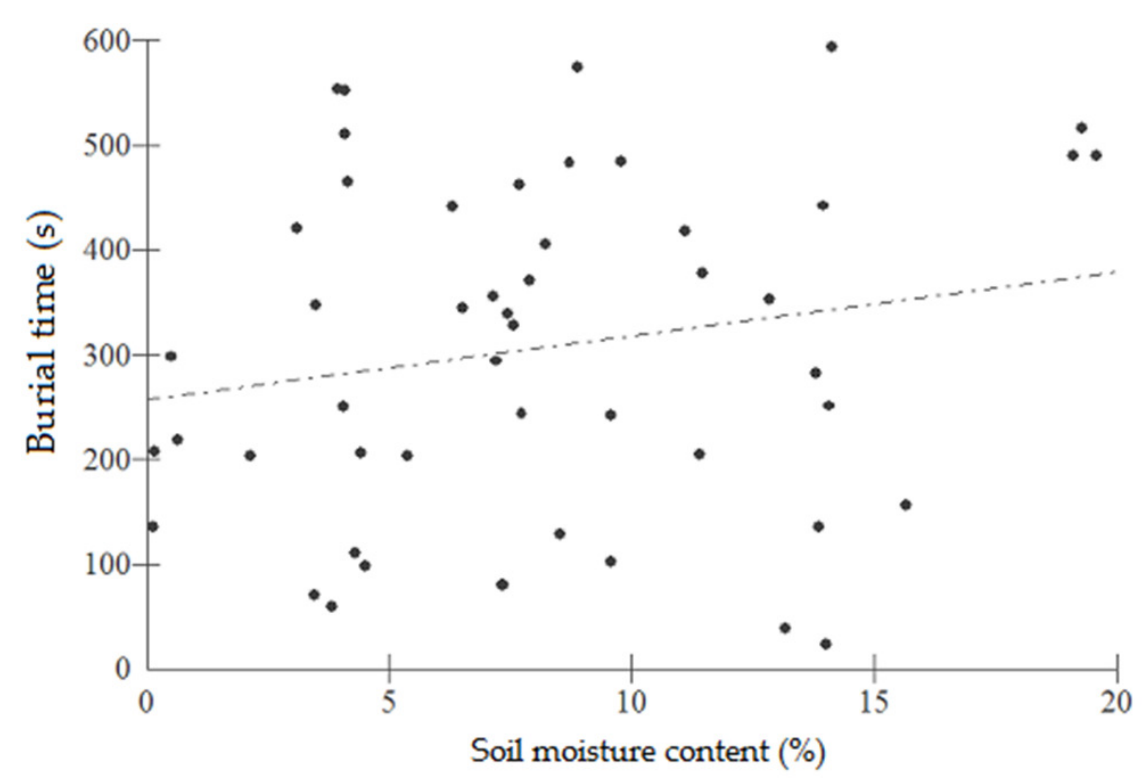

Figure 2. Linear regression of burial time (Bt, seconds) in an experiment to simulate Anastrepha fraterculus larvae leaving the fruit at a height of $30 \mathrm{~cm}$ from the ground and current soil moisture content $(\mathrm{Ug})$ $(\%)$, in a peach orchard, municipality of Morro Redondo, State of Rio Grande do Sul, Brazil between October 2014 and February 2015. 


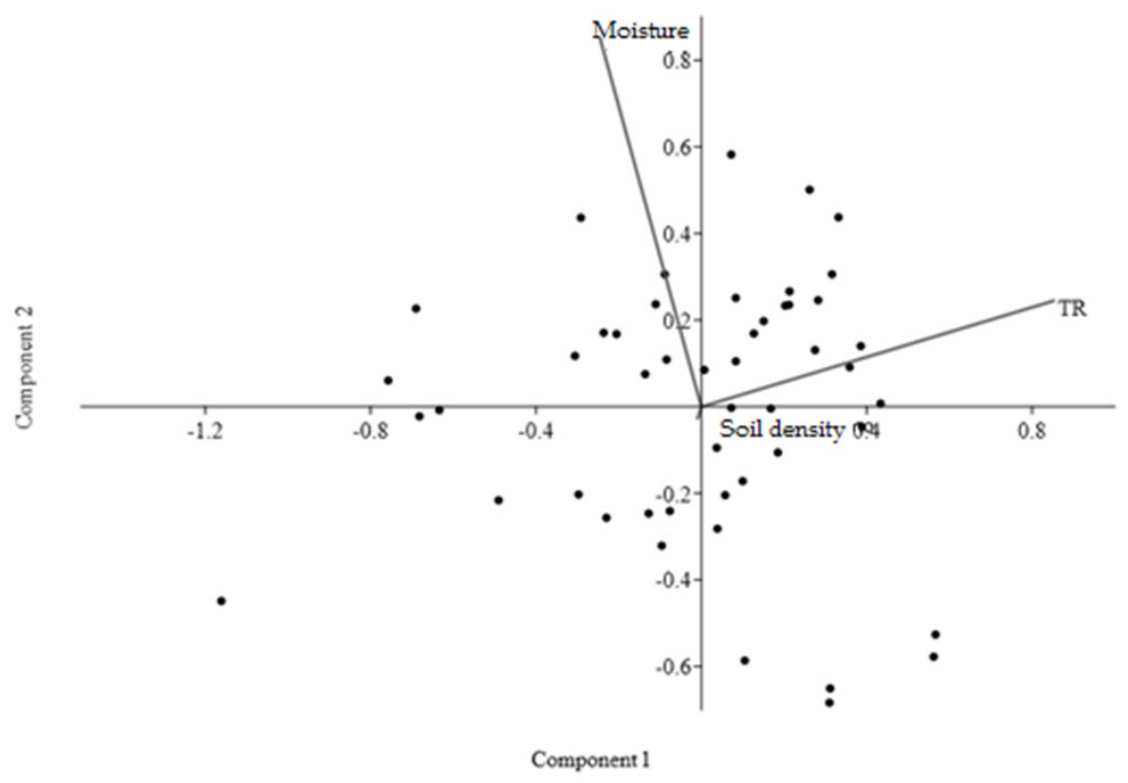

Figure 3. Principal component analysis between the time to remove (TR) the larva of Anastrepha fraterculus, density ( $\mathrm{Sd}$ ) and moisture (Gh) of the soil, in a peach orchard, municipality of Morro Redondo, State of Rio Grande do Sul, Brazil between October 2014 and February 2015.

\section{DISCUSSION}

A predatory behavior to that registered in this study was observed in larvae of the lepidopteran Cameraria ohridella Deschka et Dimić, 1986 (Gracillariidae) by the ant Crematogaster scutellaris (Olivier, 1792) (Hymenoptera: Formicidae) in Italy (RADEGHIERI, 2004). The number of predatory hymenopterans of larvae and pupae of Anastrepha exceeded the total number of predatory arthropods collected in a study developed in guava orchards (Psidium guava L., Myrtaceae), representing $88 \%$ of the total sampled predators (GALLI; RAMPAZZO, 1996). Among the predators of Anastrepha ludens Loew, 1873, ants are usually responsible for most of the observed attacks (THOMAS, 1995).

The ants removed approximately $1 / 4$ of the A. fraterculus larvae released in the peach orchard in this study, a result similar to that reported in a study of ant predation on larvae of Anastrepha spp. in orchards of Brazilian grape, guava and mango in the municipality of Dourados, State of Mato Grosso do Sul, Brazil (FERNANDES et al., 2012).

Among the genera of registered predatory ants, Pheidole presented the largest number of species, but with low removal of larvae. This data differs from that reported for this genus with $93 \%$ removal (FERNANDES et al., 2012). Ants of this genus act as efficient predators of larvae of the curculionids Conotrachelus myrciariae Marshal, 1929 and Conotrachelus psidii Marshal, 1922 (Coleoptera) (FOWLER et al.1991). Further, ants of the genus Pheidole and Solenopsis are omnivorous and dominant in soils (LUTINSKI et al., 2016). Nevertheless, the genus Solenopsis represented only by the species $S$. saevissima, showed the best removal time (approximately 43\%) of A. fraterculus larvae. Species of this genus are found in the most diverse habitats, from preserved forests (DELABIE; FOWLER, 1995) to more open environments, such as agricultural fields, because they have high invasion ability and adaptation to areas under human impact (PACHECO et al., 2009) and they have a varied diet, being able to pass long periods of food shortage and compete with other species of ants for resources more efficiently through mass recruitment (FOWLER et al., 1991). Pheidole and Solenopsis were the most efficient ants as predators of Anastrepha in the Monte Alto region São Paulo State, Brazil (GALLI; RAMPAZO, 1996) and Solenopsis invicta Buren, 1972 of Anastrepha suspensa (Loew, 1862) in star fruit (Averrhoa carambola L., Oxalidaceae) orchards, in Florida, United States (HENESSEY, 1997).

The fruit flies, especially those belonging to the genus Anastrepha, rapid penetration into the soil is the best strategy to prevent predation (THOMAS, 1995; ALUJA et al., 2005); soil properties as well as the ability of larvae to bury are determinants for their survival (FERNANDES et al., 2012). The lack of moisture in the soil can lead to the mortality of pupae and newly emerged adults, which have difficulty passing through dry soils (BAKER et al., 1944) and affect the predation rate by ants 
(FERNANDES et al., 2012). In addition, the frequency of ants is higher when there are lower values of rainfall and soil moisture (SANTOS et al., 2012). In our study, the physical properties of the soil were significantly important for the removal of larvae by the ants. Anastrepha fraterculus larvae move intensely and disperse, attracting predatory ants of the genus Solenopsis (SALLES; CARVALHO, 1993), corroborating what was observed in this study. Moreover, larval penetration is faster in soil with high organic matter content, which makes the soil less compacted (ALUJA et al., 2005).

The predominance of the attacks by ants on A. fraterculus larvae show the importance that ants can play in the agroecosystem, functioning as a conservative biological control agent, becoming an interesting component in pest management programs and drawing attention to the benefits of conservation of these species against the use of combined control methods that aim at the reduction of insecticides as well as the management of the soil.

\section{CONCLUSIONS}

Ants belonging to the genera Pachycondyla, Pheidole, Pogonomyrmex and Solenopsis are important predators of $A$. fraterculus larvae.

The species $S$. saevissima contributes as a conservation biocontrol agent and, in addition, enable future studies involving different combinations such as the evaluation of the crop type, cultivation method and pesticides used against the effect on the species mentioned above.

\section{ACKNOWLEDGMENTS}

We thank the Coordination for the Improvement of Higher Education Personnel (CAPES) for the scholarship of PCG and the postdoctoral of AMN and to National Council for Scientific and Technological Development (CNPq) for Research Productivity Grant to FRMG.

RESUMO: Formigas (Hymenoptera, Formicidae) são eficientes como predadores de diversos artrópodes. Baseado nos registros de atividade predatória de formigas, um levantamento da eficiência na predação de larvas de Anastrepha fraterculus (Diptera: Tephritidae) considerando a porcentagem na remoção das larvas pelas formigas frente às variáveis de densidade e teor de umidade do solo e o seu efeito sobre o tempo de enterramento das larvas, foi realizado. Larvas de A. fraterculus foram liberadas ao solo e observadas por 10 min enquanto enterravam-se ou eram removidas pelas formigas em um pomar de pessegueiro (Prunus persica, Rosaceae). Oito espécies de formigas foram registradas removendo $32.7 \%$ das larvas oferecidas. Solenopsis saevissima foi a espécie mais eficiente com $42.9 \%$ da remoção de larvas. Não ocorreram correlações significativas entre os registros de predação por formigas com a densidade e o teor de umidade do solo. Apesar disso, o estudo apontou que as formigas pertencentes aos gêneros Pachycondyla, Pheidole, Pogonomyrmex e Solenopsis podem ser predadoras de larvas de A. fraterculus, com ênfase na espécie $S$. saevissima, podem contribuir como importantes agentes de controle biológico conservativo da população de A. fraterculus em pomar de pessegueiro e que sua conservação torna-se interessante frente ao uso de métodos de controle combinados visando a redução de inseticidas e de métodos agressivos de manejo do solo.

PALAVRAS-CHAVE: Inimigos naturais. Mosca-da-fruta sul-americana. Prunus persica. Manejo ecológico de pragas.

\section{REFERENCES}

ALBERTI, S.; GARCIA, F. R. M. ; BOGUS, G. M. Moscas-das-frutas (Diptera: Tephritidae) em pomares de pessegueiro e maracujazeiro no município de em Iraceminha, Santa Catarina. Ciência Rural, v. 39, n. 5, p. 1565-1568, 2009. https://doi.org/10.1590/s0103-84782009005000077

ALUJA, M.; SIVINSKI, J.; RULL, J.; HODGSON, P. J. Behavior and predation of fruit fly larvae (Anastrepha spp.) (Diptera: Tephritidae) after exiting fruit in four types of habitats in tropical Veracruz, Mexico.

Environmental Entomology, v. 34, n. 6, p. 1507-1516, 2005. https://doi.org/10.1603/0046-225x-34.6.1507 
ALVARES, C. A.; STAPE, J. L.; SENTELHAS, P. C.; GONÇALVES, J. L. M.; SPAROVEK, G. Köppen's climate classification map for Brazil. Meteorologische Zeitschrift, v. 22, n. 6, p. 711-728, 2013. https://doi.org/10.1127/0941-2948/2013/0507 BAKER, M. A.; STONE, W. E; PLUMMER, C. C.; MCPHAIL, M. A review of studies on the Mexican fruit fly and related Mexican species. USDA Miscellaneous Publications, v. 531, n. 1, p. 1-155, 1944.

DELABIE, J. H. C.; FOWLER, H. G. Soil and litter cryptic ant assemblages of Bahian cocoa plantations. Pedobiologia, v. 39, n. 5, p. 423-433, 1995.

DUARTE, P. A. S.; ANDALÓ, V.; GARCIA, F. R. M. Faunal analysis and population density of fruit flies (Diptera: tephritidae) in an orchard located in the central western region of Minas Gerais, Brazil. Bioscience Journal, v. 32, n. 4, p. 960-968, 2016. https://doi.org/10.14393/bj-v32n4a2016-33321

ESKAFI, F. M.; KOLBE, M. M. Predation on larval and pupal Ceratitis capitata (Diptera: Tephritidae) by the ant Solenopsis geminata (Hymenoptera: Formicidae) and others predators in Guatemala. Environental Entomology, v. 19, n. 1, p. 148-153, 1990. https://doi.org/10.1093/ee/19.1.148

FERNANDES, W. D.; SANT'ANA, M. V.; RAIZER, J.; LANGE, D. Predation of fruit fly larvae Anastrepha (Diptera: Tephritidae) by ants in grove. Psyche, v. 1, n. 1, p. 1-7, 2012. https://doi.org/10.1155/2012/108389

FERNÁNDEZ, F. Introducción a las hormigas de la región Neotropical. Bogotá, Colombia: Instituto de Investigación de Recursos Biologícos Alexander von Humboldt, 2003. https://doi.org/10.21068/d100818oc

FOWLER, H. G.; FORTI, C.; BRANDÃO, C. R. F.; DELABIE, J. H. C.; VASCONCELOS, H. L. 1991. Ecologia nutricional de formigas. 131-223pp in PANIZZI, A. R.; PARRA, J. R. P. (Org.). Ecologia nutricional de insetos e suas implicações no manejo de pragas. Manole, São Paulo, Brazil. https://doi.org/10.1590/s0102$311 \times 1993000100013$

GALLI, J. C.; RAMPAZZO, E. F. L. Enemigos naturales de Anasatrepha (Diptera, Tephritidae) capturados con trampas de suelo emhuertoss de Psidium guajava. Boletín de Sanidad Vegetal Plagas, v. 22, n. 2, p. 297-300, 1996.

GARCIA, F.R.M.; RICALDE, M.P. Augmentative biological control using parasitoids for fruit fly management in Brazil. Insects, v. 4, n. 1, p. 55-70, 2013. https://doi.org/10.3390/insects4010055

HAMMER, O.; HARPER, D. A. T.; RIAN, P. D. PAST: Palaeonthological statistics software package for education and data analysis. Palaeontologia Electronica, v. 4, n. 1, p. 1-9, 2001.

HENESSEY, M. K. Predation on wandering larvae and pupae of Caribbean fruit fly (Diptera: Tephritidae) in guava and carambola grove soils. Journal of Agricultural Entomology, v. 14, n. 2, p. 129-138, 1997.

LUTINSKI, J. A.; BAUCKE, L.; FILTRO, M.; BUSATO, M. A.; KNAKIEWICZ, A. C.; GARCIA, F. R. M. Ant assemblage (Hymenoptera: Formicidae) in three wind farms in the State of Paraná, Brazil. Brazilian Journal of Biology, v. 77, n. 1, p. 1-9, 2016. https://doi.org/10.1590/1519-6984.14115

MARRONE, P. G.; STEINER, R. E. Effects of soil physical factors on egg survival of the bean leaf beetle, Ceratoma trifurcata (Forster) (Coleoptera: Chrysomelidae). Environmental Entomology, v. 12, n. 1, p. 673679, 1983. https://doi.org/10.1093/ee/12.3.673

MARSARO JUNIOR, A. L.; DEUS, E. G.; RONCHI-TELES, B.; ADAIME, R.; SILVA JUNIR, R. J. Species of Anastrepha (Diptera: Tephritidae) captured in a guava orchard (Psidium guajava L., Myrtaceae) in Boa Vista, Roraima, Brazil. Brazilian Journal of Biology, v. 73, n. 4, p. 879-886, 2013. https://doi.org/10.1590/s1519-69842013000400026 
MARTINS, L. N.; LARA, A. P. S. S.; FERREIRA, M. F.; NUNES, A. M.; BERNARDI, D.; LEITE, F. P. L.; GARCIA, F. R. M. Biological Activity of Bacillus thuringiensis (Bacillales: Bacillaceae) in Anastrepha fraterculus (Diptera: Tephritidae). Journal of Economic Entomology, v. 111, n. 3, p. 1486-1489, 2018. https://doi.org/10.1093/jee/tox364

NICÁCIO, J.; OLIVEIRA, I.; UCHOA, M A.; FACCENDA, O.; ABOT, A. R.; FERNANDES, M. G. ; GARCIA, F. R. M. Sequential sampling plan for fruit fly species of the Genus Anastrepha (Diptera: Tephritidae) in guava orchards. Anais da Academia Brasileira de Ciencias, n. 4, v. 90, p. 3607-3614, 2018. https://doi.org/10.1590/0001-3765201820180211

NUNES, A. M.; COSTA, K. Z. ; FAGGIONI, K. M. ; COSTA, M. L. Z. ; GONCALVES, R. S. ; WALDER, J. M. M. ; GARCIA, M. S.; NAVA, D. E. Dietas artificiais para a criação de larvas e adultos da mosca-dasfrutas sul-americana. Pesquisa Agropecuária Brasileira, v. 48, n. 10, p. 1309-1314, 2013. https://doi.org/10.1590/s0100-204x2013001000001

PACHECO, R.; SILVA, R. R.; MORINI, M. S. C.; BRANDÃO, C. R. F. A comparison of the leaf-litter ant fauna in a secondary Atlantic Forest with an adjacent pine plantation in southeastern Brazil. Neotropical Entomology, v. 38, n. 1, p. 55-65, 2009. https://doi.org/10.1590/s1519-566x2009000100005

PORTO, M. L. Os campos sulinos, sustentabilidade e manejo. Ciência \& Ambiente, v. 24, n. 24, p. 119-138, 2002.

RADEGHIERI, P. Cameraria ohridella (Lepidoptera Gracillaridae) predation by Crematogaster scutellaris (Hymenoptera Formicidae) in Northern Italy (Preliminary note). Bulletin of Insectology, v. 57, n. 1, p. 63-64, 2004.

REGNIERE, J.; RABB, R. L; STEINER, R. E. Popilia japonica: effect of soil moisture and texture on survival and development of eggs and first instar grubs. Environmental Entomology, v. 10, n. 5, p. 654-660, 1981. https://doi.org/10.1093/ee/10.5.654

ROACH, S. H.; CAMPBELL, R. B. Effects of soil compaction on bollworm (Lepidoptera: Noctuidae) moth emergence. Environmental Entomology, v. 12, n. 6, p. 1883-1886, 1983. https://doi.org/10.1093/ee/12.6.1883

SALLES, L. A. B.; CARVALHO, F. L. C. Profundidade da localização da pupária de Anastrepha fraterculus (Wied.) (Diptera, Tephritidae) em diferentes condições de solo. Anais da Sociedade Entomológical do Brasil, v. 22, n. 2, p. 299-305, 1993. https://doi.org/10.1590/s0301-80591998000300016

SANTOS, S. R. Q.; VITORINO, M. I.; HARADA, A. Y.; SOUZA, A. M. L.; SOUZA, E. B. A riqueza de formigas relacionada aos períodos sazonais em Caxiuanã durante os anos de 2006 e 2007. Revista Brasileira de Meteorologia, v. 27, n. 3, p. 307-314, 2012. https://doi.org/10.1590/s0102-77862012000300005

THOMAS, D. B. Predation on the soil inhabiting stages of the Mexican fruit fly. Southwestern Entomologist, v. 20, n. 1, p. 61-71, 1995.

VELOSO, V. R. S.; PEREIRA, A. F.; RABELO, L. R. S.; CAIXETA, C. V. D.; FERREIRA, G. A. Moscasdas-frutas (Diptera, Tephritidae) no Estado de Goiás: ocorrências e distribuição. Pesquisa Agropecuária Tropical, v. 42, n. 3, p. 357-367, 2012. https://doi.org/10.1590/s1983-40632012000300015 